\title{
Chapter 9 Anxiety in medical students, during a COVID-19 pandemic
}

\section{Capítulo 9 Ansiedad en estudiantes de medicina, durante pandemia COVID-19}

CACERES-MATTA, Sandra V. $\dagger^{*}$, ZÁRATE-DEPRAECT, Nikell E., FLORES-FLORES, Paula and BUSTILLOS-TERRAZAS, Nora A.

Universidad del Sinú. School of Medicine, Mexico.

Universidad Autónoma de Sinaloa. School of Medicine, Mexico.

Universidad Autónoma de Sinaloa. School of Nutrition and Gastronomy, Mexico.

ID $1^{\text {st }}$ Author: Sandra V., Caceres-Matta / ORC ID: 0000-0001-8277-607X

ID $1^{\text {st }}$ Co-author: Nikell E., Zárate-Depraect / ORC ID: 0000-0002-3087-3959

ID $2^{\text {nd }}$ Co-author: Paula, Flores-Flores / ORC ID: 0000-0003-2929-2134

ID $3^{\text {rd }}$ Co-author: Nora A., Bustillos-Terrazas / ORC ID: 0000-0002-1558-6855

DOI: $10.35429 /$ H.2021.13.107.112

S. Caceres, N. Zárate, P. Flores and N. Bustillos

*senibaza@hotmail.com

A. Marroquín, J. Olivares, M. Cruz, L. Cruz. (Coord.) CIERMMI Women in Science TXIII Medicine and Health Sciences. Handbooks-@ECORFAN-México, Querétaro, 2021. 


\begin{abstract}
Know the presence of anxiety in medical students from a private university in Colombia, during the COVID-19 pandemic. Non-experimental, quantitative, exploratory cross-sectional study; applied the DASS-21 scale. Cronbach's alpha of the total scale was 0.79 . Descriptive analysis was carried out in statistical package spss v21, data collection was by google forms during the month of December 2020, with prior informed consent. The convenience sample consisted of 115 students from the medical school of a private university in the city of Cartagena, Colombia. Of this, 60 were women and 55 men. 80 students were anxious (medium, moderate, severe, and very severe). Very severe and severe anxiety was more frequently expressed in women. It is concluded that during the COVID-19 pandemic, 80 of 115 medical students from a private university in Cartagena Colombia presented anxiety.
\end{abstract}

\title{
Anxiety, Students, Medicine
}

\section{Resumen}

Conocer la presencia de ansiedad en estudiantes de medicina de una universidad privada de Colombia, durante la pandemia COVID-19. Estudio no experimental, cuantitativo, exploratorio de corte transversal; aplicó la escala DASS-21. El alpha de Cronbach de la escala total, fue de 0 .79. Se realizó análisis descriptivo en paquete estadístico spss v21, la recolección de datos fue por Google forms durante el mes de diciembre del 2020, bajo previo consentimiento informado. La muestra por conveniencia se conformó por 115 estudiantes de la facultad de medicina, de una Universidad privada de la ciudad de Cartagena Colombia. De ello, 60 fueron mujeres y 55 hombres. 80 estudiantes resultaron con ansiedad (media, moderada, severa y muy severa). La ansiedad muy severa y severa se expresó con más frecuencia en mujeres. Se concluye que durante la pandemia COVID-19, 80 de 115 estudiantes de medicina de una universidad privada de Cartagena Colombia presentaron ansiedad.

\section{Ansiedad, Estudiantes, Medicina}

\subsection{Introduction}

The year 2020 and so far in 2021 has been difficult for the general population due to the pandemic of the new coronavirus in all its variants. This virus is considered highly contagious, causing rapid, severe and sometimes fatal infections. This has had a negative impact on the mental health of all people, forcing social isolation, fear, loneliness and uncertainty to prevail in some people, and in the educational context to migrate from face-to-face to virtual education. As a result, it altered the psychological well-being of many students and generated anxiety in them.

In Asian countries, the school population was one of the most affected, provoking anxiety in them, generated by the uncertainty of family income and that in turn required technological equipment for their educational activities (Sigüenza \& Vílchez, 2021). Isolation measures included the promotion of education through virtual platforms (Saravia, Cazorla \& Cedillo, 2020). At Changzhi University, out of 7143 medical students, 24.9\% had anxiety due to the pandemic (Garcia-Espinosa, Ortiz-Jiménez, Botello-Hernández, Hernández-Díaz, Góngor-Rivera, \& Gecen, 2021).

Garcia-Espinosa, et al. (2021), also reported that, out of 530 medical students in Saudi Arabia, $38.11 \%$ reported being emotionally tired and $56.22 \%$ acknowledged a decrease in their academic ability during this pandemic. Finally, they state that the predisposing factors: being female, knowing someone with symptomatology and being a non-clinical semester student, generated moderate-severe anxiety in $61.3 \%$ of 348 medical students.

At the same time, varying levels of anxiety were found in medical students at the National University of San Agustín, who are single, live alone and spend a lot of time listening to news about COVID-19. (Chambilla, 2021). Similarly, in students with anxiety in the health area in the Lambayeque region, having repetitive thoughts about becoming infected or infecting family members are influential as triggering factors (Zafra, 2021). (Zafra, 2021) 
Likewise, in contemporary society, anxiety is common among young people, affecting their emotional and mental well-being (Ali \& Cerkez, 2020). Medical students in Mexico believe that having been infected with COVID-19 or having a family member infected with COVID-19 or being the cause of death generated depression in them. (Yusvisaret, Palmer, Medina \& López, 2021).

Today, within the university educational environment, the fulfilment of theoretical and practical skills is demanded as if continuing in the face-to-face context (prior to the COVID-19 pandemic). The pandemic has forced virtual education to take both students and teachers by surprise in order for them to appropriate the teaching and learning strategies that this modality implies. Therefore, the academic environment is different from the traditional one, making information and communication technologies the main and indispensable tools.

Therefore, the concern of educational institutions to offer optimal teaching requires visualising the entire educational context, which is why it is important to detect manifestations that hinder students' learning. In this regard, the psychological well-being of medical students is important and some of them may show anxiety, i.e. agitation and restlessness in their mood, which can disrupt learning. This is a behavioural disorder considered to be a prevalent illness worldwide (Sousaa, Santiago \& Micó, 2020).

In relation to the above, the academic load that university students take each semester can affect the mental health of students in some way (Trunce, Villarroel, Arntz, Muñoz \& Werner, 2020). It is well known that anxiety increases as the university student tends to procrastinate (Araoz \& Uchasara, Altamirano, 2020). The medical student is subjected to a demanding, demanding and socially constrained work environment, which can sometimes be hostile and promote greater vulnerability to developing psychological disorders such as anxiety.

Before the pandemic, it was already known that about $20 \%$ of medical students show traits of anxiety and depression in the psychological profile for entry to this career. (Alvarez, 2020). In the first years of medical school, more anxious students have been observed (Caicedo, Díaz \& Vidal, 2020) and even with depression and suicidal behaviours; with more prevalence in the last grades of the professional career. (Cosme, 2020) Also, during the medical internship year, anxious men score higher than women (Huarcaya, 2020).

Because the pandemic has brought about higher levels of mood distress, this study expects to find that at least $30 \%$ of the students surveyed suffer from anxiety, either at a severe or very severe level.

\subsection{Method}

The aim of this study was to determine the presence of anxiety in medical students at a private university in Colombia during the COVID-19 pandemic.

It was carried out under a non-experimental, quantitative, exploratory and cross-sectional methodology; the anxiety scale DASS-21 (Antúnez, 2012) was applied, which deals with how they felt during the past week and includes: moods, signs of nervousness, desire to live, desire to do activities, etc. Cronbach's alpha of the total scale was 0.79 . Descriptive analysis was carried out using the statistical package spss v21, and the scale was applied using the google forms platform during the month of December 2020, with prior informed consent. The convenience sample consisted of 115 medical students from a private university in the city of Cartagena, Colombia.

\subsection{Results and discussion}

Of the 115 students who participated in this study, according to the gender variable, 60 were female and 55 were male. As can be seen in Table 1, the number of students can be seen in relation to the level of anxiety they manifested. In this sense, 80 students were found to have anxiety (medium, moderate, severe and very severe).

Very severe anxiety was expressed by 30 students, predominantly by 18 females. Severe anxiety was also more frequent in females, while moderate and medium anxiety predominated in males. 
Table 9.1 Anxiety levels in medical students in Colombia

\begin{tabular}{|l|r|r|}
\hline \multicolumn{1}{|c|}{ Range } & Total & \multicolumn{1}{c|}{ Gender } \\
\hline Normal & 35 & $\begin{array}{r}20 \text { women } \\
15 \text { men }\end{array}$ \\
\hline Medium & 9 & $\begin{array}{r}4 \text { women } \\
6 \text { men }\end{array}$ \\
\hline Moderate & 19 & $\begin{array}{r}5 \text { women } \\
14 \text { men }\end{array}$ \\
\hline Severe & 22 & $\begin{array}{r}13 \text { women } \\
8 \text { men }\end{array}$ \\
\hline Very severe & 30 & $\begin{array}{r}18 \text { women } \\
12 \text { men }\end{array}$ \\
\hline
\end{tabular}

Source: Own elaboration, 2020

With the above, we agree with authors such as Sigüenza and Vílchez (2021), in assuring that during COVID isolation, anxious students did show up, as they perceived a greater academic load, affecting their mental and emotional well-being (Ali \& Cerkez, 2020; Trunce, Villarroel, Arntz, Muñoz \& Werner, 2020).

Likewise, it has been shown internationally that university students, especially in the area of health, tend to manifest anxious symptoms (Apaza \& Gonza, 2020). According to Solernou and Solernou (2020), one in five university students suffers from anxiety disorder, and he refers to the fact that this could become an epidemic. High percentages of anxiety were found in medical students (Ruvalcaba, González \& Jiménez, 2021), which reinforces the result found in this study.

Furthermore, it is in agreement with several studies stating that anxiety is more frequent in women than in men (López, Moreno \& Sánchez, 2020; Quesada, Gutiérrez, Gutiérrez, Nouni, \& Carratalá, 2021; Luna, Urquiza, Figuerola, Carreño \& Meneses, 2020. And also with Luna, et al., 2020; Caicedo, Díaz and Vidal, 2020, who state that women who study medicine have more anxiety than men.

Although the causal factors of anxiety were not addressed in this study, however, it was considered relevant to investigate the current literature on them and the following was found:

- When the student is in the evaluation period, anxiety is more evident. (Nolasco, 2020).

- $\quad$ Living alone, having less than 5 hours for recreation, lack of time to eat, sleeping less than 5 hours, requiring more than 90 minutes to travel to the university. (Pinilla, López, Moreno \& Sánchez, 2020).

- The level of anxiety increases as a function of curricular development, and among its main sources are academic, psychosocial and economic aspects (Luna, Urquiza, Figuerola, Carreño, \& Meneses, 2020; Puig, Ricaño, Quiroz \& Puig (2021).

- $\quad$ Sleep disturbances are associated with anxiety, poor performance of daily bodily tasks, depressive disorders, memory problems, academic and motivational problems, suicidal thoughts, obesity and cardiac morbidity. (Ramon, Cahuich \& Lopez 2020)

\subsection{Conclusion and recommendations}

- Anxiety was manifested in 80 out of 115 medical students at a private university in Colombia during the COVID-19 pandemic.

- It predominated in women.

The implementation of promotion and prevention strategies for anxiety control is recommended, such as: family and social support, sleeping 6 to 8 hours a day, allowing time for recreation and physical activity every day.

- $\quad$ Students are encouraged to recognise stressors and self-manage their own learning. 
- Early diagnosis is requested in order to monitor and control the student who suffers from it and thus promote their emotional wellbeing, which has an impact on their learning and warn that it may evolve into depression, stress or Burnout syndrome, among others.

The fear of catching the disease and infecting a family member can theoretically be considered a factor that generates anxiety in university students.

We agree with Piñer, Gómez-Roso and López (2021) in mentioning that clinical rotations in the training of doctors during the COVID-19 pandemic are possible and necessary, as long as they are carried out appropriately with safety measures.

\subsection{References}

UAntúnez, Z. y Vinet, E. V. (2012). Escala de depresión, ansiedad y estrés (DASS-21): validación de la versión abreviada en estudiantes universitarios chilenos. Terapia psicológica. 30(3). 49-55. https://scielo.conicyt.cl/pdf/terpsicol/v30n3/art05.pdf

Ali, Ahmed, S. y Cerkez, Y. (2020). El impacto de la ansiedad, la depresión y el estrés en la estabilidad emocional entre los estudiantes universitarios desde el punto de vista educativo. Propósitos y Representaciones. 8(3). 1-9. http://dx.doi.org/10.20511/pyr2020.v8n3.520

Alvarez, A. M. (2020). Perfil psicológico en estudiantes de medicina en universidad del cusco/psychological profile in medicine students at university in cusco. Situa. 23(1). 118. https://doi.org/10.51343/si.v23i1.191

Apaza Ramirez, B. R., y Gonza Chunga, C. E. (2020). Relación entre religiosidad y ansiedad en estudiantes de una universidad privada de Lima Este. [Tesis para Profesional de Psicólogo(a), en la Universidad Peruana Unión]. Repositorio de Tesis Universidad Peruana Unión. https://repositorio.upeu.edu.pe/handle/20.500.12840/3076

Araoz, E. G. E., y Uchasara, H. J. M. (2020). Procrastinación académica y ansiedad en estudiantes universitarios de Madre de Dios, Perú. Apuntes Universitarios, 10(4), 322-337. https://doi.org/10.17162/au.v10i4.517

Chambilla Rodriguez, C. A. (2021). Factores asociados y nivel de ansiedad frente a COVID-19 en estudiantes del sexto año de la facultad de medicina de la Universidad Nacional de San Agustín, mayo 2021

Caicedo, N. K., Díaz, L. P., \& Vidal, V. L. (2020). Niveles de ansiedad y depresión en estudiantes de ciencias de la salud que usan dispositivos móviles [Tesis Doctoral, Universidad Santiago de Cali]. Repositorio Universidad Santiago de Cali. https://repository.usc.edu.co/handle/20.500.12421/5045

Cosme, J. A. et al (2020). Depresión, ansiedad y conducta suicida en la formación médica en una universidad en México. Revista Investigación en Educación Médica, 9(35), 65-74. https://doi.org/10.22201/facmed.20075057e.2020.35.20224

Luna, D. et al. (2020). Predictores académicos y sociodemográficos de ansiedad y bienestar psicológico en estudiantes mexicanos de medicina. Estudio transversal. Gaceta Médica de México. 156. 40-46. http://dx.doi.org/10.24875/GMM.19005143

Lagunes, Á. A. et al. (2020). Prevalencia de depresión, ansiedad y estrés académico entre estudiantes de medicina, durante distintos periodos de estrés. Atención Familiar, 27(4), 165-171. http://dx.doi.org/10.22201/fm.14058871p.2020.4.76891

Pinilla, L. M. et al. (2020). Prevalencia y factores de riesgo de Ansiedad en estudiantes de medicina de la Fundación Universitaria Juan N. Corpas. Un estudio de corte transversal. Revista Cuarzo, 26(1), $22-$ 27. https://revistas.juanncorpas.edu.co/index.php/cuarzo/article/view/493/439 
Puig-Lagunes, Á. A. et al. (2021). Sintomatología de ansiedad y burnout al término de la licenciatura de médico cirujano. Revista de la Facultad de Ciencias Médicas de Córdoba, 78(1), 25-28. http://dx.doi.org/10.31053/1853.0605.v78.n1.28447

Garcia-Espinosa, P., Ortiz-Jiménez, X., Botello-Hernández, E., Hernández-Díaz, A., GóngoraRivera, F., \& Gecen Investigators. (2021). Covid-19, impacto psicosocial en estudiantes de medicina. Salud Pública de México, 63(3 May-Jun), 330-331.

Gutiérrez, I. et al. (2021). Depresión, ansiedad y salud autopercibida en estudiantes de Medicina: un estudio transversal. Revista Española de Educación Médica, 2(2), 21-31. doi: 10.6018/edumed.470371

Piñel Pérez, C. S., Gómez-Roso Jareño, M. J., \& López Galián, J. J. (2021). Percepción y ansiedad de los estudiantes de Medicina en su rotación clínica en Obstetricia durante la pandemia por COVID-19.

Ramón, L. A. et al. (2020). Calidad de sueño, somnolencia diurna y ansiedad en estudiantes de la carrera de médico cirujano en una universidad privada del norte de México PsicoSophia, 2(1), 12-19, http://psicosophia.um.edu.mx/ojs/index.php/psicosophia/article/view/13/10

Ruvalcaba, K. A. et al. (2021). Depresión y ansiedad en estudiantes de Medicina durante el confinamiento por la pandemia de COVID-19. Investigación edn educación médica, 10(39), 1-8. https://doi.org/10.22201/fm.20075057e.2021.39.21342

Saravia-Bartha, M. M. et al. (2020). Nivel de ansiedad de estudiantes de medicina de primer año de una universidad privada del Perú en tiempos de covid-19. Revista Facultad de Medicina Humana, 20(4), 568-573. DOI 10.25176/RFMH.v20i4.3198

Sigüenza, W. G. y Vílchez, J. L. (2021). Aumento de los niveles de ansiedad en estudiantes universitarios durante la época de pandemia de la COVID-19. Revista Cubana de Medicina Militar. 50(1). 1-14. http://www.revmedmilitar.sld.cu/index.php/mil/article/view/931/731

Solernou, A. J. y Solernou, I.A. (2020, 26-30 de octubre). Factores socio-familiares, académicos, ansiedad y depresión, en estudiantes de medicina. Fundamentación de exploración necesaria. En Primera $\begin{array}{llll}\text { Jornada Virtual de Psiquiatría. } & \end{array}$ http://jvirtualpsiquiatria2020.sld.cu/index.php/jvpsq/2020/paper/view/112

Sousaa, J. et al. (2020). Ansiedad comparada entre estudiantes de medicina y estudiantes de otros grados en el Área de la Salud en Coimbra. Educación médica, 20, 130-134. https://doi.org/10.1016/j.edumed.2020.04.001

Trunce, S. T. et al. (2020). Niveles de depresión, ansiedad, estrés y su relación con el rendimiento académico en estudiantes universitarios. Investigación en educación médica, 9(36), 8-16. https://doi.org/10.22201/fm.20075057e.2020.36.20229

Yusvisaret Palmer, Lourdes, Palmer Morales, Sefnar, Medina Ramirez, Ma. Concepción Rosa, \& López Palmer, Daniel Alexis. (2021). Prevalencia de depresión durante la COVID-19 en estudiantes de medicina de una universidad privada mexicana. MEDISAN, 25(3), 637-646. Epub 07 de junio de 2021. Recuperado en 10 de agosto de 2021, de http://scielo.sld.cu/scielo.php?script=sci_arttext\&pid=S1029$30192021000300637 \& \operatorname{lng}=\mathrm{es} \&$ tlng=es.

Zafra Rodas, J. J. (2021). Prevalencia de ansiedad y depresión en internos de ciencias de la salud de la región Lambayeque durante pandemia por COVID-19, 2020-2021. 